\title{
Comparison of Compressive Strength of Concrete by Partial Replacement of Cement with GGBS and Silica Fume with Sea Water Curing and Addition with Fibers
}

\author{
A Aswani ${ }^{1} \mid$ Janardhan $G^{2}$ \\ ${ }^{1}$ Postgraduate student, Visakha Technical Campus, Andhra Pradesh, India. \\ ${ }^{2}$ Assistant professor, Visakha Technical Campus, Andhra Pradesh, India.
}

To Cite this Article

A Aswani and Janardhan G, "Comparison of Compressive Strength of Concrete by Partial Replacement of Cement with GGBS and Silica Fume with Sea Water Curing and Addition with Fibers", International Journal for Modern Trends in Science and Technology, Vol. 07, Issue 02, February 2021, pp.-31-39.

Article Info

Received on 15-January-2021, Revised on 28-January-2021, Accepted on 03-February-2021, Published on 07-February-2021.

\section{ABSTRACT}

In construction world concrete plays a vital role, around $60 \%$ of structure consists of Concrete. However, the production of Portland cement, an essential constituent of concrete, leads to the release of significant amounts of $\mathrm{CO}_{2}$, depletion of natural resources and environmental degradation. This paper investigates the compressive strength of concrete by replacing cement with GGBS and silica fume effect of glass fibers on performance of concrete is studied. In this present work a humble attempt had been made to evaluate and compare the compressive strengths of GGBS blended concrete cubes with controlled concrete cubes cured under sea water for 28 days. By conducting the tests on the cubes, conclusions were drawn after plotting and analyzing the results. Compressive strength test is conducted on the samples after 28 days. The optimum value is obtained at 15\% replacement with GGBS and 5\% with Silica fume. In this study again we trailed addition with Glass fibers with the percentage of $0.5 \%, 1.0 \%, 1.5 \%$, compressive strength have been studied. Finally at 1.0\% addition we get maximum strength compared to controlled mix.

Keywords: GGBS, Glass fibers, Sea water Compressive strength.

\section{INTRODUCTION}

Concrete occupies a unique position among modern construction materials. It is the only material manufactured at construction sites. It gives considerable freedom to the architect to mould the structural element to any shape or form a freedom that is not possible with other materials. Of course, concrete has limitations it cannot, on its own, flow past obstructions and into nooks and crannies. Through compaction, often using vibration is essential for achieving strength and durability of concrete. As concrete is produced and placed at construction sites, under conditions far from ideal, we do often end up with unpleasant results rocks pockets, sand streaks and a host of workmanship related problems.

The extensive use of concrete is not only in construction of residential buildings but also silos for many factories where sometimes chemicals may have to be stored and even the residential buildings are being constructed beside sea, marine structures like deck bridges etc. undergo contact with lots of salts thus care is to be taken for such constructions since durability of the structure may be affected. Thus many researches are being done for a better durable concrete feasible for use in 
construction of such structures. Blended concrete, which would reduce the contact area of cement with salts, would be a better solution to overcome any unwanted reactions between minerals in cement and salts in contact. GGBS and Silica fume blended concrete has evolved as an innovative technology, capable of achieving the status of being an outstanding advancement in the sphere of concrete technology. As so many construction companies are using the GGBS in their projects. The utilization of GGBS and Silica fume will reduce the dumping and as well as decrease the construction cost also.

\section{LITERATURE REVIEW}

SuvarnaLatha estimated the GGBS efficiency. The utilization of supplementary cementitious materials is well accepted because of the several improvements possible in the concrete composites, and due to the overall economy. The present paper is efforts to quantify the strength of ground granulated blast furnace slag (GGBS) and high volume fly ash (HVFA) at the various replacement levels and evaluate their efficiencies in concrete. In recent years GGBS when replaced with cement has emerged as a major alternative to conventional concrete and has rapidly drawn the concrete industry attention due to its cement savings, energy savings, and cost savings, environmental and socio-economic benefits. The present study reports the results of an experimental study, conducted to evaluate the strengths and strength efficiency factors of hardened concrete, by partially replacing the cement by various percentages of ground granulated blast furnace slag and high volume fly ash for M20, M40 and M60 grades of concrete at different ages. The overall strength efficiency was found to be a combination of general efficiency factor, depending on the age and a percentage efficiency factor, depending upon the percentage of replacement. Here an effort is made towards a specific understanding of the efficiency of GGBS and Fly ash in concrete, considering the strength to water cement ratio relations, age and percentage of replacement. The optimum GGBS and Fly ash replacement as cementitious material is characterized by high compressive strength, low heat of hydration, resistance to chemical attack, better workability, and good durability and cost-effective. From this study it can be concluded that, since the grain size of GGBS is less than ordinary Portland cement, its strength at earlyis less but continues to gain strength over a long period.
Peter explained that the hydraulic potential of blastfurnace slag was first discovered in Germany in 1862. In 1865, lime-activated blastfurnace slag started to be produced commercially in Germany and in 1880 GGBS was first used in combination with Portland cement (Concrete Society, 1991). In Europe, GGBS has been used for over 100 years. In North America, the history of the use of GGBS in quality concrete dates back about 50 years (Yazdani, 2002). In Southeast Asian countries including Mainland China and Hong Kong, GGBS was used in concrete in around 1990. Between 1955 and 1995, about 1.1 billion tonnes of cement was produced in Germany, about 150 million tonnes of which consisted of blast furnace slag (Geiseler et al, 1995). In China, the estimated total GGBS production was about 100 million tonnes in 2007 (Chen, 2006).

GGBS has been widely used as a partial replacement of Portland cement in construction projects. In Western Europe, the amount of GGBS used accounts for about $20 \%$ of the total cement consumed, whereas in the Netherlands it accounts for $60 \%$ of the total cement consumption (Tsinghua University, 2004). There are abundant examples of the use of GGBS concrete in construction projects. In New York, the concrete used in the construction of the World Trade Centre has about 40\% GGBS replacement (Slag Cement Association, 2005). At the Minneapolis Airport, the airfield pavements were constructed using concrete with 35\% GGBS replacement. Other projects using GGBS include the world's largest aquarium - the Atlanta's Georgia Aquarium which used 20\% to $70 \%$ GGBS replacement. The Detroit Metro Airport Terminal Expansion used concrete with 30\% GGBS replacement. The Air Train linking New York's John F. Kennedy International Airport with Long Island Rail Road trains used concrete with $20 \%$ to $30 \%$ GGBS replacement. In China, GGBS has been widely used in major construction projects such as the Three Gorges Dam, Beijing-Shanghai Express Rail, and Cross-bay Bridge of Hangzhou Bay. The GGBS replacement level is generally around 40\% (China Cements, 2009; China Biz, 2009).

Preeti stated that the effect of salt water on the compressive strength of concrete was investigated. This paper therefore presents the result and findings of an experimental research on the effect of salt water on compressive strength of concrete. For this concrete cubes were cast using fresh wi and salt water for a design mix of M- 30 
1:1.8:3.31 by weight of concrete, and 0.45 watercement ratio. Half of concrete cubes were cast and cured with fresh water and remaining half cubes were cast and cured with salt water. The concrete cubes were cured for 7,14 and 28 days respectively. The result of the average compressive strength of concrete obtained using fresh water ranges from $27.12-39.12 \mathrm{~N} / \mathrm{mm} 2$ and using salt water ranges from $28.45-41.34 \mathrm{~N} / \mathrm{mm}^{2}$.

Abalaka concluded that the study investigated the effects of sodium chloride $(\mathrm{NaCl})$ solutions as curing medium at concentrations of $5 \%$ and $10 \%$ on compressive strength of concrete cubes containing $5 \%$ rice husk ash (RHA). Concrete cubes containing 5\% RHA in $\mathrm{NaCl}$ solutions show early compressive strength increase at 3 and 7 days over control cubes; at 28 days concrete cubes containing 5\% RHA cured in $\mathrm{NaCl}$ solutions recorded higher strength loss compared to control cubes.

Oultoge 2014 presents the experimental investigations on the effect of sea water on the compressive strength of concrete. Cement concrete cubes of $150 \mathrm{~mm} \times 150 \mathrm{~mm} \times 150 \mathrm{~mm}$ were cast using fresh water and sea water with mix ratio $1: 2: 4$. All the mixes were prepared using constant water cement ratio $(\mathrm{w} / \mathrm{c})$ of 0.6 by weight. A total of 140 concrete cubes were made in two batches; half of the cubes were made using fresh water and the other half using sea water. They were cured in fresh and sea water respectively. The curing was done for $7,14,21,28$ and 90days, then crushed using the Compressive Strength Test Apparatus at prescribed ages. The study shows an increase in the compressive strength of concrete for concrete specimens mixed and cured with sea water. Compressive strength of the concrete were also affected when the concrete was cast with fresh water and cured with salt water and vice-versa.

\section{EXPERIMENTAL WORK \\ Cement:-}

Cement is a fine, grey powder. It is mixed with water and materials such as sand, gravel crushed stone to make a concrete. The ordinary cement contains two basic ingredients namely argillaceous and calcareous. In argillaceous materials, clay predominates and in calcareous materials calcium carbonate predominates. Ordinary Portland cement of grade -53 (KCP cement) conforming to Indian standards (IS: 12269-1987) has been used in the present study.

\section{GGBS:-}

To produce GGBS, this granulated blast furnace slag is dried and ground to a fineness similar to that of Portland cement. GGBS is normally used in combination with Portland cement. The GGBS and cement are added into the concrete mixer as separate constituents. Where appropriate, the ratio of GGBS to cement can be varied according to the technical requirements for any particular application.

\section{Silica fume:-}

Silica fume is a byproduct of producing silicon metal or ferrosilicon alloys. One of the most beneficial uses for silica fume is in concrete. Because of its chemical and physical properties, it is a very reactive pozzolanic. Concrete containing silica fume can have very high strength and can be very durable

\section{Physical properties of fly ash \& GGBS and silica fume}

\begin{tabular}{|c|c|c|c|c|c|}
\hline S.No & IS Code & Tests performed & \multicolumn{3}{|c|}{ Results } \\
\cline { 4 - 6 } & & & Cement & GGBS & Silica fume \\
\hline 1 & IS $12089: 1987$ & Specific gravity & 3.13 & 2.82 & 2.63 \\
\hline 2 & IS $12089: 1987$ & Fineness & $7.2 \%$ & $7 \%$ & $14 \%$ \\
\hline
\end{tabular}

\section{Fine and Coarse aggregate}

Fine aggregate used in this study was locally available river sand of Zone II compliing to IS 383:1970. The specific gravity, water absorption and fineness modulus of fine aggregate used was $2.55,0.806 \%$ and 2.58 .

Locally procured coarse aggregate from local quarry was used in this investigation. The specific gravity, Bulk density and Water absorption used was $2.9,1738 \mathrm{~kg} / \mathrm{m}^{3}$ (compacted), $1512 \mathrm{~kg} / \mathrm{m}^{3}$ (loosely packed) and $0.502 \%$.

\section{Water}

Water is a key ingredient in the manufacture of concrete. And in this investigation water participates in the chemical reaction with $\mathrm{NaOH}$ pellets. Since it helps to the strength giving binder gel, the quantity and quality of water are required to be looked into very carefully.

\section{Super Plasticizer}

To improve the workability of the silica/RHA based geopolymer concrete, conplast SP 430 super plasticizer which is obtained from FOSROC Constructive Solution Company. And also it served as a high range water reducer. The colour of the 
conplast is brown liquid and dosage of conplast added as $3 \%$ by weight of binder material.

\section{Glass fiber}

Glass fiber is a recent introduction in making fiber concrete. Fig.5 shows glass fiber reinforced concrete (GFRC) much like you would find in fiberglass insulation, to reinforce the concrete. The glass fiber helps insulate the concrete in addition to making it stronger. Glass fiber also helps prevent the concrete from cracking over time due to mechanical or thermal stress. In addition, the glass fiber does not interfere with radio signals like the steel fiber reinforcement does.

\section{PHASE I}

Percentage of replacements

\begin{tabular}{|c|c|c|c|c|c|c|c|c|c|c|c|}
\hline Mix designation & MSN & MSS & M1N & $\begin{array}{c}\mathrm{M} 1 \\
\mathrm{~S}\end{array}$ & M2N & $\begin{array}{c}\text { M2 } \\
\text { S }\end{array}$ & M3N & $\begin{array}{c}\text { M3 } \\
\text { S }\end{array}$ & M4N & $\begin{array}{c}\text { M4 } \\
\text { S }\end{array}$ & $\begin{array}{c}\text { Unit } \\
\mathrm{s}\end{array}$ \\
\hline Cement & 100 & 100 & 90 & 90 & 85 & 85 & 80 & 80 & 75 & 75 & $\%$ \\
\hline GGBS & 0 & 0 & 5 & 5 & 10 & 10 & 15 & 15 & 20 & 20 & $\%$ \\
\hline Silica fume & 0 & 0 & 5 & 5 & 5 & 5 & 5 & 5 & 5 & 5 & $\%$ \\
\hline Glass fibers & 0 & 0 & 0 & 0 & 0 & 0 & 0 & 0 & 0 & 0 & $\%$ \\
\hline Fine aggregate & 100 & 100 & 100 & 100 & 100 & 100 & 100 & 100 & 100 & 100 & $\%$ \\
\hline \begin{tabular}{l|l} 
Coarse & $20 \mathrm{~mm}$
\end{tabular} & 100 & 100 & 100 & 100 & 100 & 100 & 100 & 100 & 100 & 100 & $\%$ \\
\hline \begin{tabular}{l|l} 
& $10 \mathrm{~mm}$
\end{tabular} & 100 & 100 & 100 & 100 & 100 & 100 & 100 & 100 & 100 & 100 & $\%$ \\
\hline Normal water & 100 & 0 & 100 & 0 & 100 & 0 & 100 & 0 & 100 & 0 & $\%$ \\
\hline Sea water & 0 & 100 & 0 & 100 & 0 & 100 & 0 & 100 & 0 & 100 & $\%$ \\
\hline $\mathrm{Sp}$ & 100 & 100 & 100 & 100 & 100 & 100 & 100 & 100 & 100 & 100 & $\%$ \\
\hline
\end{tabular}

PHASE II

Percentage of replacements

\begin{tabular}{|c|c|c|c|c|c|c|c|c|c|c|c|c|}
\hline \multicolumn{2}{|c|}{ Mix designation } & MSN & MSS & M2N & $\begin{array}{c}\text { M2NF } \\
1\end{array}$ & $\begin{array}{c}\text { M2NF } \\
2\end{array}$ & $\begin{array}{c}\text { M2NF } \\
3\end{array}$ & M2S & $\begin{array}{l}\text { M2S } \\
\text { F1 }\end{array}$ & $\begin{array}{c}\text { M2SF } \\
2\end{array}$ & $\begin{array}{c}\text { M2SF } \\
3\end{array}$ & Units \\
\hline \multicolumn{2}{|c|}{ Cement } & 100 & 100 & 85 & 85 & 85 & 85 & 85 & 85 & 85 & 85 & $\%$ \\
\hline \multicolumn{2}{|c|}{ GGBS } & 0 & 0 & 10 & 10 & 10 & 10 & 10 & 10 & 10 & 10 & $\%$ \\
\hline \multicolumn{2}{|c|}{ Silica fume } & 0 & 0 & 5 & 5 & 5 & 5 & 5 & 5 & 5 & 5 & $\%$ \\
\hline \multicolumn{2}{|c|}{ Glass fibers } & 0 & 0 & 0 & 0.50 & 1.00 & 1.50 & 0 & 0.5 & 1.00 & 1.50 & $\%$ \\
\hline \multicolumn{2}{|c|}{ Fine aggregate } & 100 & 100 & 100 & 100 & 100 & 100 & 100 & 100 & 100 & 100 & $\%$ \\
\hline \multirow[t]{2}{*}{$\begin{array}{c}\text { Coarse } \\
\text { aggregate }\end{array}$} & $\begin{array}{c}20 \\
\mathrm{~mm}\end{array}$ & 100 & 100 & 100 & 100 & 100 & 100 & 100 & 100 & 100 & 100 & $\%$ \\
\hline & $\begin{array}{c}10 \\
\mathrm{~mm}\end{array}$ & 100 & 100 & 100 & 100 & 100 & 100 & 100 & 100 & 100 & 100 & $\%$ \\
\hline \multicolumn{2}{|c|}{ Normal water } & 100 & 0 & 100 & 100 & 100 & 100 & 0 & 0 & 0 & 0 & $\%$ \\
\hline \multicolumn{2}{|c|}{ Sea water } & 0 & 100 & 0 & 0 & 0 & 0 & 100 & 100 & 100 & 100 & $\%$ \\
\hline \multicolumn{2}{|c|}{$\mathrm{Sp}$} & 100 & 100 & 100 & 100 & 100 & 100 & 100 & 100 & 100 & 100 & $\%$ \\
\hline
\end{tabular}

1.RESULTS AND DISCUSSIONS

Average Compressive strength of concrete cubes cured with normal water.

\begin{tabular}{|c|c|c|c|c|c|}
\hline S.No & Mix designation & \multicolumn{5}{|c|}{ Compressive strength (MPa) } \\
\cline { 3 - 6 } & & 3 days & 7 days & 14 days & 28 days \\
\hline 1 & MSN & 19.20 & 28.80 & 43.20 & 48.00 \\
\hline 2 & MSS & 18.20 & 27.30 & 40.95 & 45.50 \\
\hline 3 & M1N & 17.00 & 25.50 & 38.25 & 42.50 \\
\hline 4 & M2N & 19.00 & 28.50 & 42.75 & 47.50 \\
\hline $\mathbf{5}$ & M3N & $\mathbf{2 0 . 5 0}$ & $\mathbf{3 0 . 7 5}$ & $\mathbf{4 6 . 0 0}$ & $\mathbf{5 1 . 5 0}$ \\
\hline 6 & M4N & 19.00 & 28.50 & 42.75 & 47.50 \\
\hline
\end{tabular}




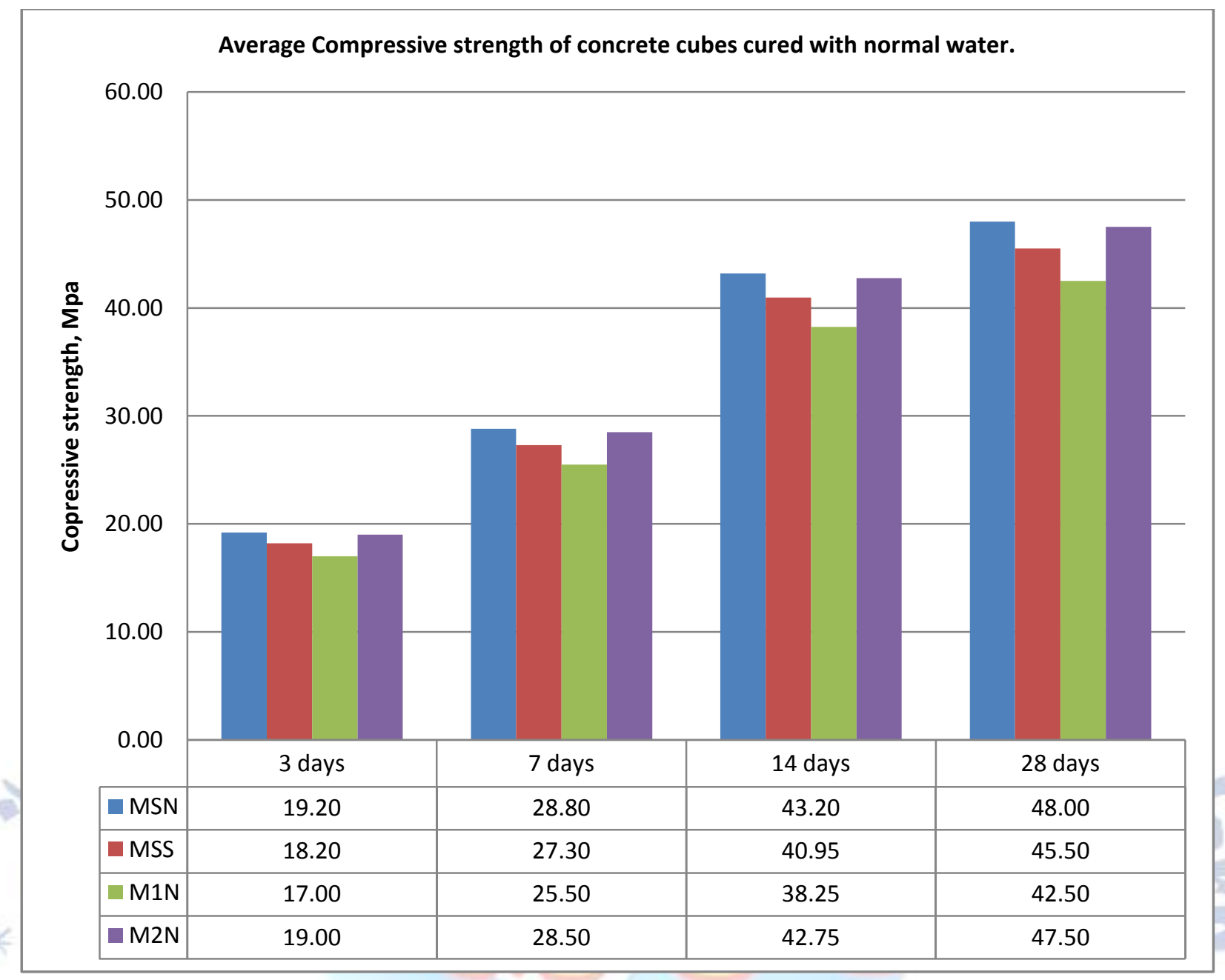

Average Compressive strength of concrete cubes cured with sea water.

\begin{tabular}{|c|c|c|c|c|c|}
\hline \multirow{2}{*}{ S.No } & Mix designation & \multicolumn{4}{|c|}{ Compressive strength (MPa) } \\
\cline { 3 - 6 } & & 3 days & $\mathbf{7}$ days & $\mathbf{1 4}$ days & 28 days \\
\hline 1 & MSN & 19.20 & 28.80 & 43.20 & 48.00 \\
\hline 2 & MSS & 18.20 & 27.30 & 40.95 & 45.50 \\
\hline 3 & M1S & 17.20 & 25.80 & 38.70 & 43.00 \\
\hline 4 & M2S & 17.80 & 26.70 & 40.05 & 44.50 \\
\hline $\mathbf{5}$ & M3S & $\mathbf{1 9 . 6 0}$ & $\mathbf{2 9 . 4 0}$ & $\mathbf{4 4 . 1 0}$ & $\mathbf{4 9 . 0 0}$ \\
\hline 6 & M4S & 18.40 & 27.60 & 41.40 & 46.00 \\
\hline
\end{tabular}




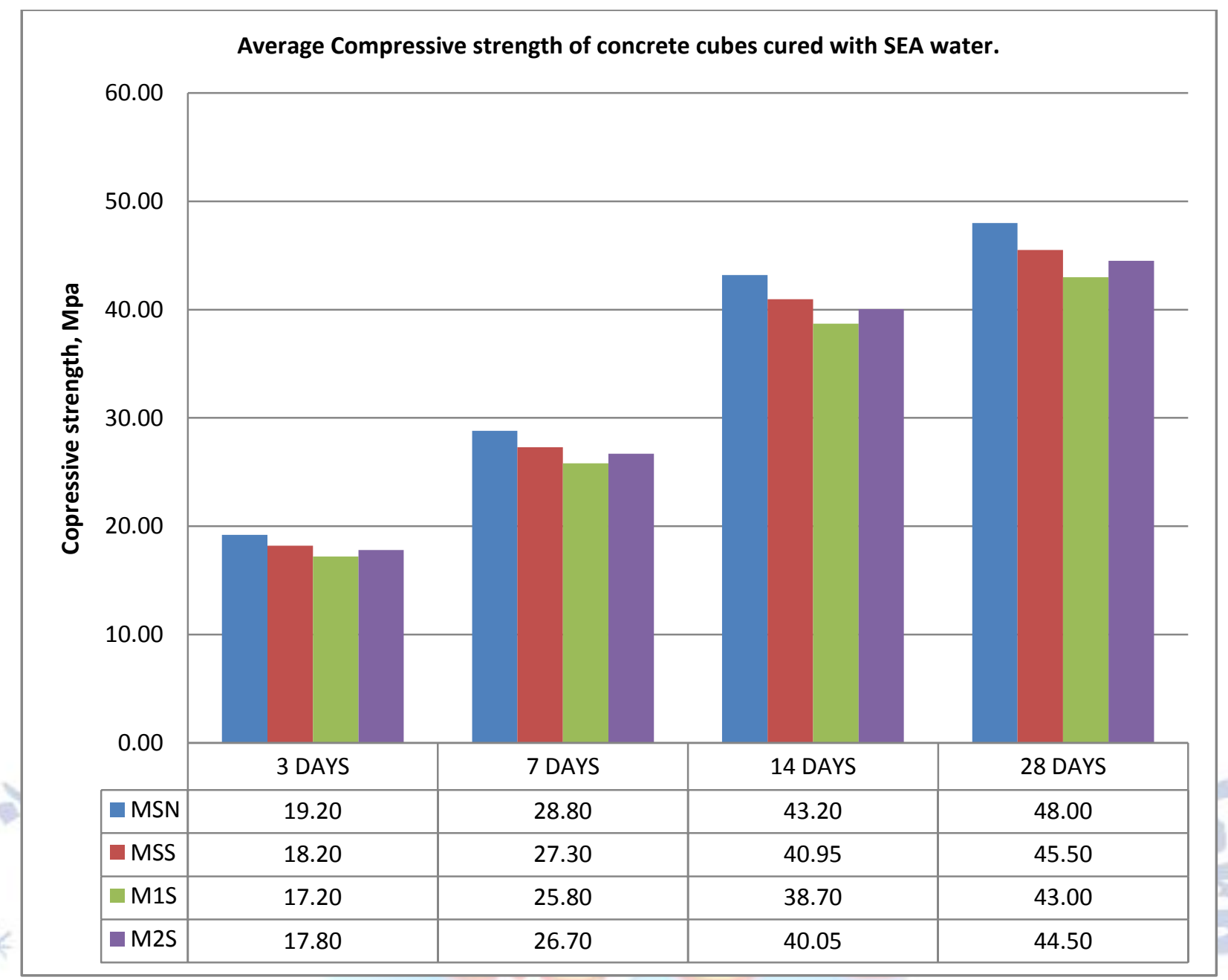

Average Compressive strength of concrete cubes cured with normal water And addition with fibers.

\begin{tabular}{|c|c|c|c|c|c|}
\hline \multirow{2}{*}{ S.No } & Mix designation & \multicolumn{4}{|c|}{ Compressive strength (MPa) } \\
\cline { 3 - 6 } & & $\mathbf{3}$ days & 7 days & 14 days & 28 days \\
\hline 1 & MSN & 19.20 & 28.80 & 43.20 & 48.00 \\
\hline 2 & MSS & 18.20 & 27.30 & 40.95 & 45.50 \\
\hline 3 & M3N & 20.50 & 30.75 & 46.10 & 51.25 \\
\hline 4 & M3NF1 & 19.80 & 29.70 & 44.55 & 49.50 \\
\hline $\mathbf{5}$ & M3NF2 & $\mathbf{2 1 . 6 0}$ & $\mathbf{3 2 . 4 0}$ & $\mathbf{4 8 . 6 0}$ & $\mathbf{5 4 . 0 0}$ \\
\hline 6 & M3NF3 & 20.40 & 30.60 & 45.90 & 51.00 \\
\hline
\end{tabular}




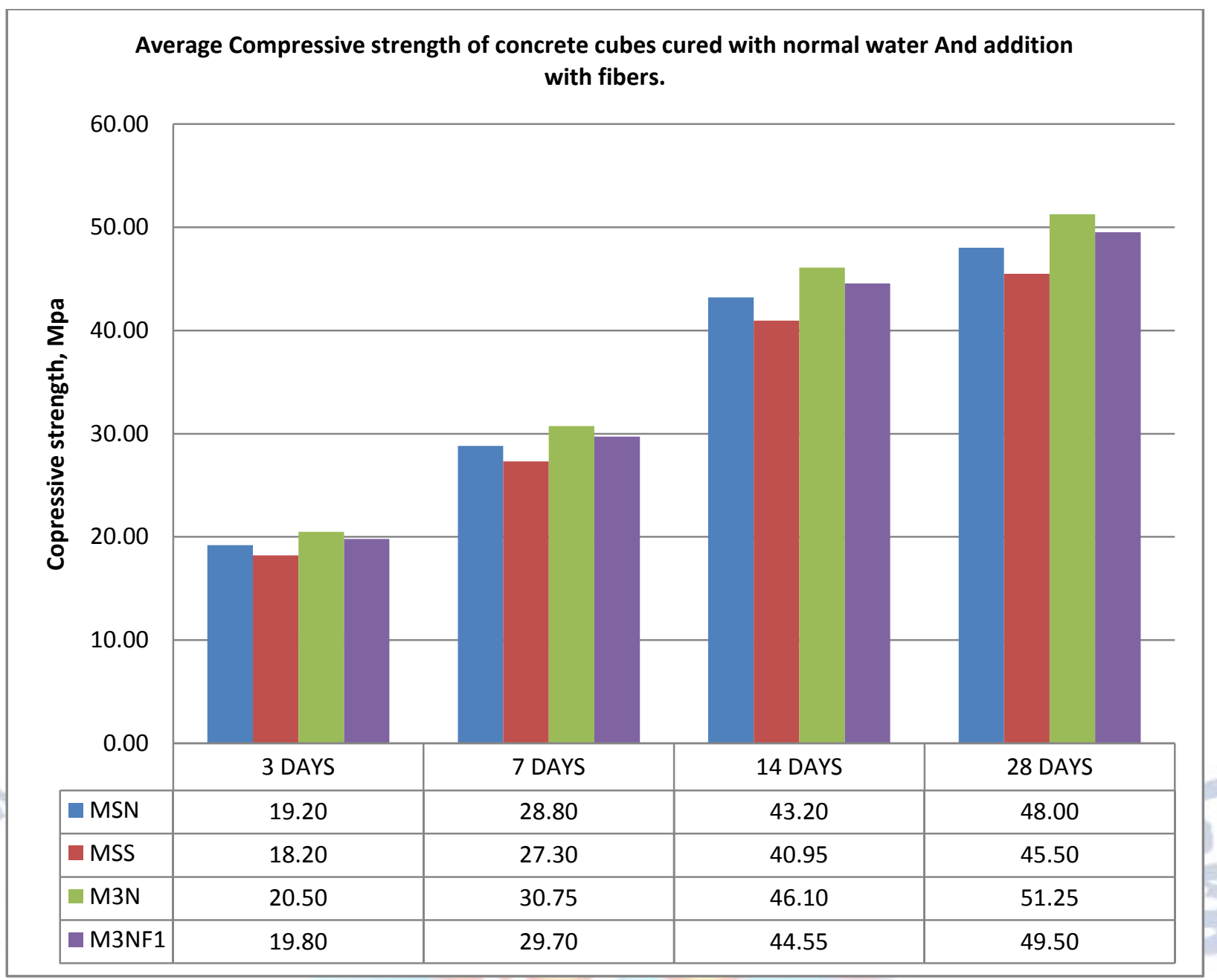

Average Compressive strength of concrete cubes cured with sea water And addition with fibers.

\begin{tabular}{|c|c|c|c|c|c|}
\hline \multirow{2}{*}{ S.No } & Mix designation & \multicolumn{4}{|c|}{ Compressive strength (MPa) } \\
\cline { 3 - 6 } & & 3 days & $\mathbf{7}$ days & 14 days & 28 days \\
\hline 1 & MSN & 19.20 & 28.80 & 43.20 & 48.00 \\
\hline 2 & MSS & 18.20 & 27.30 & 40.95 & 45.50 \\
\hline 3 & MSS & 19.60 & 29.40 & 44.10 & 49.00 \\
\hline 4 & M3SF1 & 19.20 & 28.80 & 43.20 & 48.00 \\
\hline $\mathbf{5}$ & M3SF2 & $\mathbf{2 0 . 6 0}$ & $\mathbf{3 0 . 9 0}$ & $\mathbf{4 6 . 3 5}$ & $\mathbf{5 1 . 5 0}$ \\
\hline 6 & M3SF3 & 19.80 & 29.70 & 44.55 & 49.50 \\
\hline
\end{tabular}



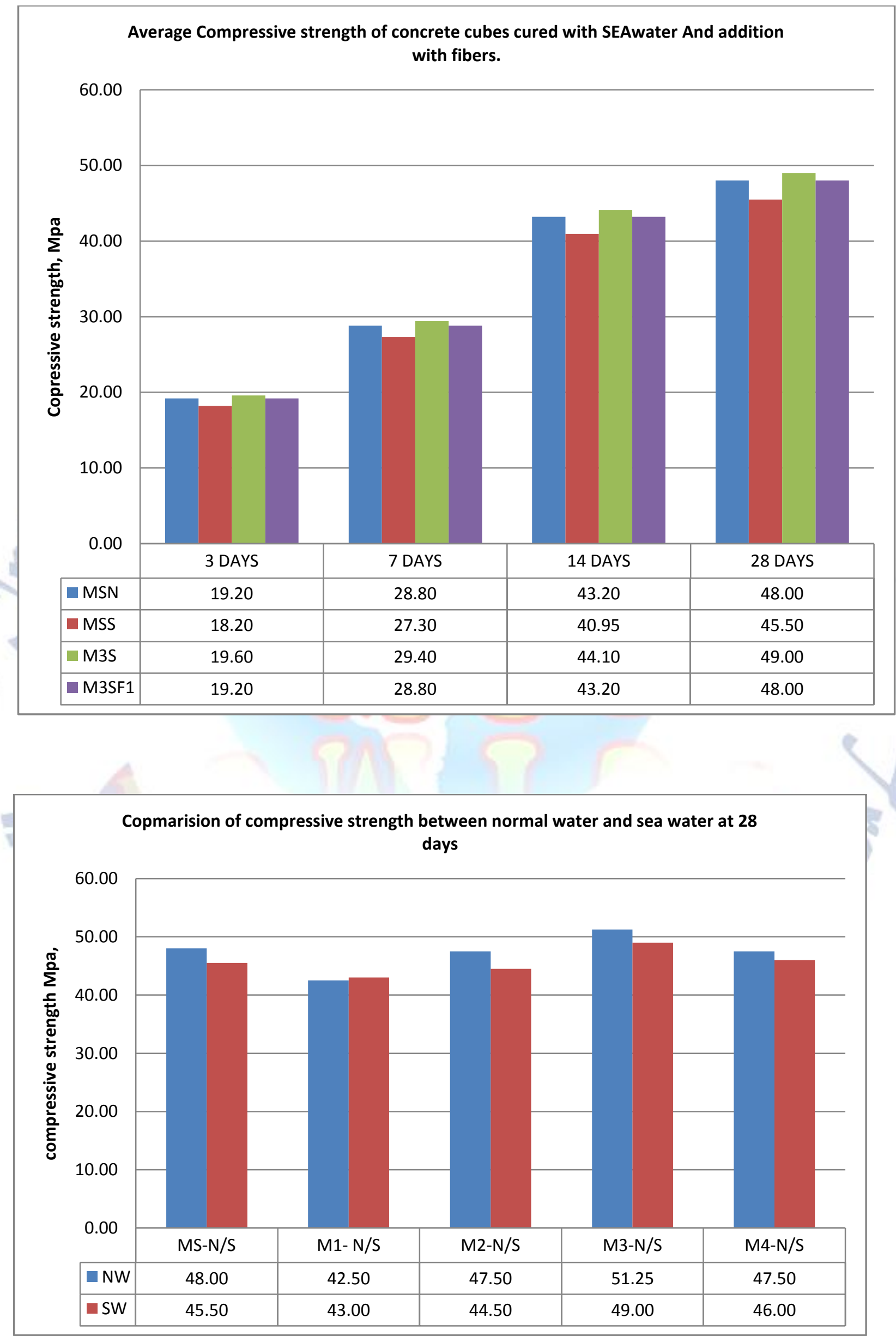


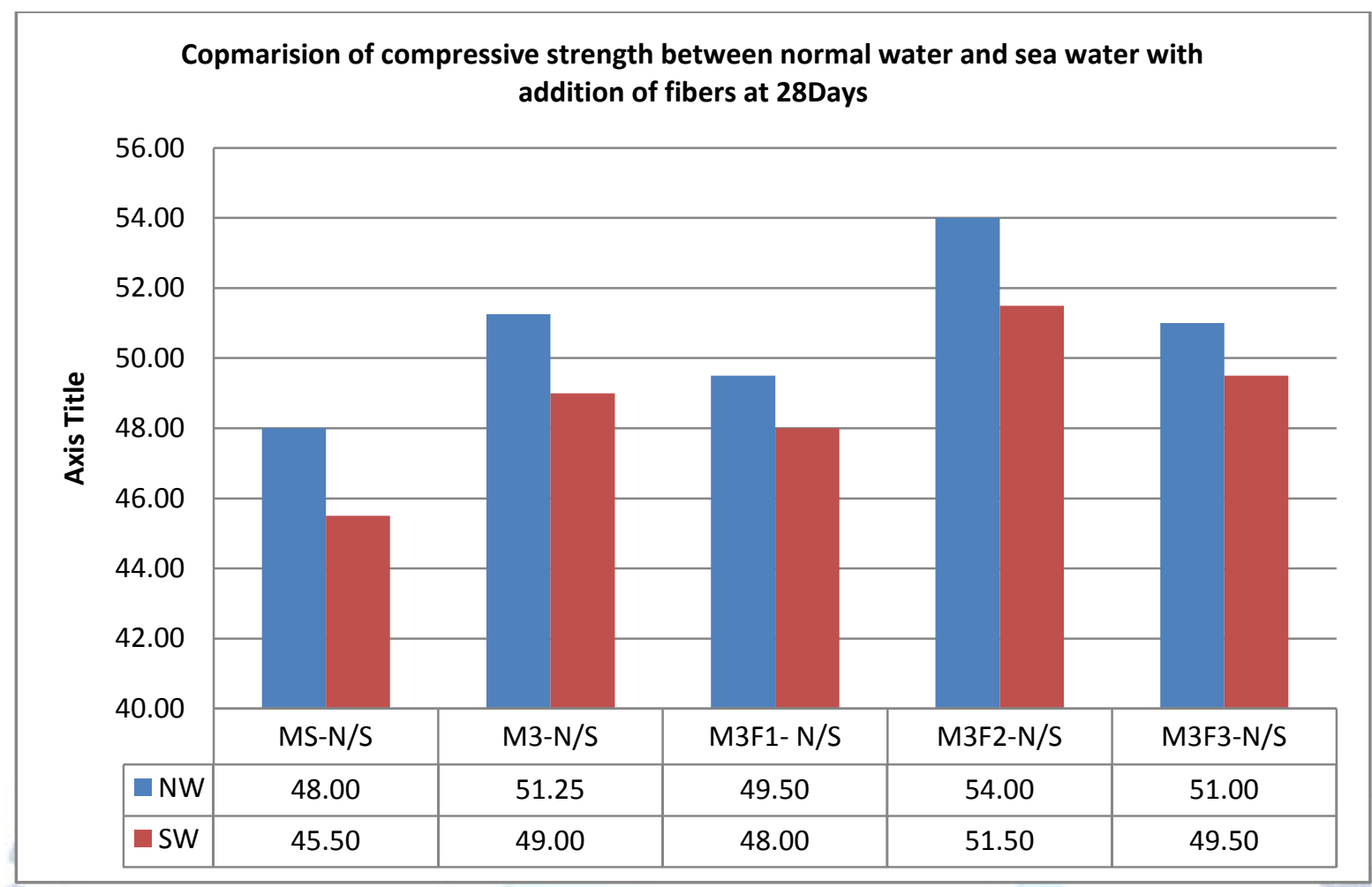

\section{CONCLUSIONS}

Based on results and discussions following conclusions were made.

$>$ A significant reduction of workability.

$>$ A progressive addition in compressive strength by increasing the percentage of GGBS and silica fume in mix.

> The inclusion of GGBS and Silica fume content in the specimen increases the density and increase the pozzolanic materials addition.

> The replacement of GGBS and silica fume in the mixtures enhances the compressive strength performance of the concrete,

$>$ The addition of fibers in the mixtures improve strength.

> The Compressive strength increases even after adding pozzolanic materials. Due to increase the fibers content. For all replacement levels of Concrete with other mixes goes on decreasing in strength when compared with parent grade ofM40.

\section{REFERANCES}

[1] Abalaka,A.E and Babalaga,A.D (December 2011), "effect of sodium chloride solution on compressive strength development of concrete containing rice Husk Ash",vol.4, pp.33-38

[2] Code practice for plain and reinforced concrete, IS 456-2000, Indian standard institution, New Delhi

[3] Indian Standards recommended guideline for concrete mix design, IS 10262-1982, Indian Standard Institution, New Delhi.
[4] Method of tests for strength of concrete, IS 516-1959, Indian Standard Institution, New Delhi.

[5] Olvtoge,F.Adeyemi and Amusan,G.Modupeola, the effect of sea water of compressive strength of concrete vol.3 Issue.7,(july 2014) pp.23-31

[6] Preeti,Tiwari et al.int. Effect of salt water on compressive strength of concrete, vol.4 (april 2014),pp.38-42

[7] Preeti,Tiwari et al.int. Effect of salt water on compressive strength of concrete, vol.4 (april 2014),pp.38-42.

[8] Specifications for coarse and fine aggregates from natural sources of concrete, IS 383- 1970, Indian Standard Institution, New Delhi.

[9] Specifications For 53 Grade OPC, IS 12269:1987, Indian Standard Institution, New Delhi.

[10] Text book "Concrete technology" by M.S. Shetty, Universal Publications. Text book "Fly ash in concrete" by V.M. Malhotra \& A.A. Ramezanian. Text book "Properties of concrete" by A.M. Neyveli.

[11] V.Venkateswara Reddy, H.Sudarsana Rao and KN.Jayaveera (April 2006) Effects of salt water on compressive strength of concrete, vol.13,pp.123-128. 